\title{
Reconstructing Migrant Identity and Language Use: A Case Study of West Papuans in Kaprus Village, Teluk Wondama Regency, West Papua, Indonesia
}

\author{
Marlon Arthur Huwae \\ Department of Anthropology, University of Papua, Manokwari, Papua Barat, Indonesia \\ Email: MarlonArthurHuwae@outlook.com
}

How to cite this paper: Huwae, M. A. (2016). Reconstructing Migrant Identity and Language Use: A Case Study of West Papuans in Kaprus Village, Teluk Wondama Regency, West Papua, Indonesia. Advances in Anthropology, 6, 93-108.

http://dx.doi.org/10.4236/aa.2016.64009

Received: September 27, 2016

Accepted: November 1, 2016

Published: November 4, 2016

Copyright $\odot 2016$ by author and Scientific Research Publishing Inc.

This work is licensed under the Creative Commons Attribution International

License (CC BY 4.0)

http://creativecommons.org/licenses/by/4.0/

(c) (i) Open Access

\begin{abstract}
The implementation of special autonomy law is to empower the natives of West $\mathrm{Pa}$ pua, Indonesia. As the locality and nativity are the main elements to access power, the status of Sougb and Wepu as the natives is threatened. This is related to the fact that they are West Papuan migrants in Kaprus. The migration of Sougb and Wepu clans to Kaprus can be scrutinized through subject right, object right, and kinds of right. Several major causes of this migration are centered on conflict, natural resources scarcity and marriage. In order to gain power and influence in Kaprus, identity reconstruction of Sougb and Wepu is carried out. It is done by utilization of Wamesa language, manipulation of clan history and social movement to control Kaprus. It is done by appointing the leader of Sougb and Wepu clan as the village leader of Kaprus.
\end{abstract}

\section{Keywords}

Migration, Special Autonomy, Social Movement, Language Use, Kaprus Village

\section{Introduction}

The identity as the indigenous people is not easily embedded onto the skin color or the physical characteristics. It should be earned by struggle and movements to convince and to obtain acceptance and consideration from the government and other native clans. This is in fact reflected on the Sougb and Wepu community inhabiting the Kaprus village, Sougb Wepu (Sougb Jaya) District, Teluk Wondama Regency. Obviously, the struggle and social movement of this clan to position and to strengthen their status 
as one of the indigenous clans of Teluk Wondama Regency have been maintained and nurtured for a series of decades. This is feasible as gradually the natives of the Kaprus village, the Wondama people gradually leave the village leaving the Sougb and Wepu as the majority of the village.

The implementation of special autonomy law in Papua has brought a new realm of freedom horizon to the natives' people in social, economic and political elements. This factor has mainly contributed to the social movement orchestrated to secure the rights of natives over the new comer (non indigenous people). The struggle and claim over the rights as the natives of the land have come to a new dimension in which each clan tries to prove their identity as the native of the land through myth, history, and story of origin that might be overlapping and contradicting. Accordingly, the conflict over natural resources extraction and claim over communal property (hak ulayat) are likely to increase dramatically.

The social movement cannot be separated from the social struggle and the power relations in social class as well as the utilization of language to exercise power. Fairclough (1989: p. 34) mentions that "language is both a site of and a stake in class struggle, and those who exercise power through language must constantly be involved in struggle with others to defend (or lose) their position". In addition, the magnitude of social struggle is likely to be related to conflict derived by domination to maximize profit and position of a group. In this case, power relations are not reducible to class relations and both class relation and class struggle are crucial to social system because class struggle is the important embedded property of social system in which the profits and the power of one class are determined by the capability to maximally exploit and to dominate other classes (Fairclough, 1989: pp. 34-35).

Accordingly, in order to analyze the language use and the social movement in Kaprus village, the social struggle (conflict), social movement, motive of use of language in formal and informal domain by the leaders of Mokiri, Sayori, Bikiai, Tubes and Bokoma clans, as well as the reason behind the utilization of language are scrutinized.

\section{Literature Review}

This section is devoted to discuss the concept related to social movement, migration, history of the clans and language use. The description of Kaprus village and the history of the clans are also explained.

\subsection{The Description of Kaprus Village}

Kaprus village represents countryside closes to sea and this village is under Sougb Wepu (Sougb Jaya) District. There are actually 5 villages under Sougb Wepu (Sougb Jaya) District namely Kaprus village, Siresi village, Nuspairo village, Reyob village and Yarmatum village. The total population of Kaprus Village is 295 people that make 81 family units. Most of the villagers make living by working as fisherman, gardener, hunter and farmer as well as the breeder of pig and chicken. As a developing village, there are many program supported by the local government to empower the community espe- 
cially by fulfilling basic necessities of the villagers in education, health and infrastructure. It is clear that the school building, sanitation, fresh water supply and equipment, electricity generator, health-care unit, and cemented road are supported by the local government. The local government also helps the villagers to establish standardized house, even though not all villagers are helped.

In their daily life, the community has bound relationship with the dog as it is considered as the guardian of the house and the helper in hunting the animals such as wild hog and deer. This is not in contrast with their belief since majority of the community is Christians. In addition, as the community embraces patriarchy, there is division of work load between male and female. The male members of the community have obligation to hunt, to fish, to prepare the land for agriculture, to make fence around the farm, to protect the farm and to sell the harvest, to manage the money from selling the harvest from the garden or farm and to make living while the female members of the community have obligation to cook, to wash the clothes, to take care of the children, to plant the seed in the garden, to watering the garden or farm and to sell the harvest.

The economy of Kaprus village is motorized by 4 kiosk owned by the new-comers from Buton and Bugis. In this case, the trade takes place between the owners of the kiosk and the local villagers because the products such as fresh fish, salt fish, and sea cucumbers are sold directly to all the merchants (kiosk owners). Moreover, the villagers also have livestock (pig) that they sell to the buyers from Prafi, Manokwari Regency and Bintuni Regency. The villagers also get income from selling the harvest from their garden or farm and compensation from logging company that conducts logging activity in communal or clan property. In terms of the social system, all villagers are bounded by the relationship resulted from marriage. Marriage in this case combines and strengthens the tie of two or more extended families.

\subsection{The History of the Clans in Kaprus Village}

The enactment of UU No. 21/2001 about special autonomy in Papua which is then followed by UU No. 35/2008 has provided the local community to exercise their rights and to strengthen their position to be the absolute leader in at the government level and "adat" institution. The additional effects of this are the claim over the origins, customary rights over the land and the natural resources, disparity between the natives with the non natives (native Papuan of a particular area VS other Papuans that are not the indigenous; native Papuan VS the mixed blood/one of the parents is not native Papuan; and native Papuan VS the non native Papuans). This is in fact reflected in Kaprus village resulted in many version of indigenous clan history. Basically, there are nine clans that shape Kaprus village; the 7 clans that live in Kaprus village are Kaikatui, Mokiri, Bikiai, Sayori, Tubes, Bokoma, Werianggi and other 2 clans that live outside Kaprus village are Arhita, and Iba.

\subsubsection{Kaikatui Clan (Wamesa Tribe)}

It is stated clearly that Kaprus used to be no man land. In the beginning, the ancestor of Kikatui clan is the first clan that inhabits Kaprus. It is stated that the ancestor of Kaika- 
tui firstly occupied Ambumi and got married with Airam from Mor. From this marriage, they have four sons namely Rio, Nukom, Muramber, Yakob, dan Hendrik. Nukom unfortunately moved from this place due to conflict. They then moved to a no man land which is later called "Karya Yei". In wamesa language Karya yei means afraid but lovely. This name is later changed to Kaprus. In Wamesa language, Kaprus means rattan. This name is later given to memorize the characteristic of the palace that is bountiful with rattan and it takes great effort to clear the rattan. After spending 10 years in this place, Nukom with his family then moved to Yombekiri. From Yombekiri, they are then moved to Wamapuri and later to Rumberpon where they spent 20 years living in this place. After that, they then moved to Warsumbon and created a great settlement there. In Warsumbon, Nukom later got married with Tat Merje Mokiri from Sougb. From this marriage, they have a son namely Yosep Kaikatui and a daughter namely Ana Kaikatui. This marriage also created a massive migration from Sougb to the coastal area due to conflict. Consequently, Nukom allowed the Sougb people to occupied Yembekiri, while Kaprus is occupied by the Kaikatui clan. In fact, because of conflict, the most of the Kikatui Clan moved from Kaprus to Yombekiri and Yomakan, while there are only two family units of Kaikatui that still live in Kaprus and did not move.

\subsubsection{Mokiri, Bikiai and Sayori Clan-The Wepu Tribe (First Version)}

It is stated that the ancestor of the Wepu tribe is Mambarupi Mokiri. He once assigned the guardians namely Yaimeki to protect the holly tabernacle (Sara) in Botak mountain while Makekoni has obligation to protect holly tabernacle in the river of Warsumbou. One day, Mambarupi visited both of them and found out that both of them commited adultery with their own sisters. Consequently, they are expelled out; Yaimeki then moved to Dusner and developed the Sayori clan while Makekoni moved to Wombo/ Naikere and developed Bikai clan. Mambarupi then leave Mapar Mokiri and did a journey and explored some places namely Bambu island, Yendumat, Yomakan, and finally settled in Kaprus. Kaprus at that time is no man land, and Mambarupi then established settlement in Kaprus. His arrival in Kaprus is then followed by waves of migration from Bikiai clan, Sayori clan and Kaikatui clan to stay at Kaprus.

\subsubsection{Bikiai Clan-The Wepu Tribe (Second Version)}

Bikiai means a person on the right side. In the beginning, the Bikiai clan occupied Yaimeki Mountain. However, because of conflict, they are then forced to move to Runaki cape. In addition because of marriage between Kaikatui clan and Bikiai clan, they then stay at Kaprus.

\subsubsection{Sayori Clan-The Sougb Tribe}

Sayori clan is descendant of Sinta/Wepu tribe that lives on Isim high land. Sayori is in fact the name of the mountain on Isim high land. The ancestor of Sayori clan is Jom. Jom has one son named Mambo and two daughters named Miera and Tebrero. The Mokiri clan is in fact established from the blood line of Jom. Tebrero bear a son named Mahiro. Mahiro has a son named Jombri and a daughter named Tisupa. Jombri has a son named Jupter. Tisupa has two sons named Kaleb Sayori and Set Sayori. Set Sayori 
has a son named Wellem Sayori, Barnadus Sayori, Yulianus Sayori and Yulius Sayori. Miera then got married with Sukotmetko from Ista. They got a son named Icara. He got two sons named Ub and Rotjum. Ub got married with Suku Ita from Ista and they got a son named Simon Sayori. In addition because of living on the highland, the main source of protein is rat and this is exacerbated with conflict. Miera asked Icara to move to the coastal area and some Sougb clan also moved to the coastal area. After moving to the coastal area, the Ub descendants changed their identity to Sayori as their clan.

Rotjum got married with Tosoho Tubes. Simon Sayori got married with Naomi Arhita and they got a son named Yulianus Sayori and a daughter named Sofia Sayori. Yulianus Sayori got three daughters named Sartika Sayori, Deborah Sayori, and Monika Sayori. Sofia Sayori got married with Yesaya Sayori and they got a daughter named Maria Sayori and three sons named Saul Sayori, Marinus Sayori, and Markus Sayori. Marianus Sayori got married with Isak Tubes and they got a son named Orgenes Tubes. Saul Sayori got married with Aprida Sayori and they got a son named Marfer Sayori and a daughter named Monika Sayori. Marianus Sayori got married with Terriana Iba and they got two sons named Yulianus Sayori, Yanto Sayori and a daughter named Naomi Sayori.

\subsubsection{Mokiri, Bikiai and Sayori Clan-The Wepu Tribe (Third Version)}

Wepu or Befu tribe is actually the collaboration of three major clans namely Mokiri, Sayori Wepu dan Bikiai. This tribe originally occupied the high land of Mokiri and then they moved to the south and they then arrived at Wamsiru. They then stayed there temporarily and moved to Bambu Island. From the Bambu Island they moved to the north and they approached Yendumat. Since the World War II hit Papua, they then moved to Yomakan and lived together with Kaikatui clan. After the Worl War II, they returned to the Bambu Island. Then, Yohanes Mokiri left Bambu Island and settled down at Worparen River in Kaprus. He then asked his entire clan to live with him. At that time, the Kaikatui clan occupied Kaprus. As there is missionary who spread the values of Christianity, a church is then built in Kaprus. The Mokiri clan and the Kaikatui clan are heavily influenced by Christianity values and they then become Christians. Because of this, the Mokiri clan lived together with the Kaikatui Clan in Kaprus because there is only one church; the church is only found in Kaprus.

\subsubsection{Tubes Clan-The Sougb Tribe}

Tubes clan is originally from the Isim Highland. The movement of Tubes clan to the coastal area is caused by conflict. Tubes are actually the name of the river in the highland of Isim. The ancestor of Tubes clan is Umakau Tubes. Umakau Tubes got a son named Steika Tubes. Steika Tubes got a son named Matou Tubes. Matou Tubes got a son named Sohoro tubes. Sohoro Tubes got a son named Uria Tubes. Uria Tubes got a son named Alberth Tubes. Alberth Tubes got a son named Permenas Tubes. The Tubes clan can stay in Kaprus, as they are permitted by the Mokiri Clan.

\subsubsection{Bokoma Clan-The Sougb Tribe}

Bokoma clan is originally from Bokoma Mountain in the highland of Isim. Because of 
conflict with Ahorem clan, the Bokoma clan was forced to leave their village and moved together with Tubes Clan to Yarmatum. From Yarmatum, they moved to Sabin and finally they got settled at Kaprus with Kaikatui and Mokiri clans. It is also stated that the Bokoma ever became the allies of the Mokiri clan. Bokoma also can stay at Kaprus because the Mokiri allows them to stay.

\subsubsection{Werrianggi Clan-The Wamesa Tribe}

Werianggi clan is actually developed from Gotlif Werianggi. He has been living in Kaprus since 1966. He worked there as the teacher who is then promoted as the headmaster of the school. He then retired in 2002 and he is now playing a key role as the linchpin in "adat" institution, religion institution, and community institution. He is absolutely sage with the custom and manner of the indigenous people as well as their origins.

\subsubsection{Arhita Clan-The Sougb Tribe}

Arhita clan is originally from the high land of Isim. Arhita is actually the name of the mountain in the highland of Isim. They moved to the coastal area due to fierce conflict. The ancestor of Arhita clan is Mohiri Arhita. Mohiri Arhita has a son named Tohokus Arhita. He then has a son named Aitemes Arhita and a daughter named Atefro Arhita. Aitemes Arhita has a son named Bernadus Arhita and a daughter named Naomi Arhita. Atefro Arhita has a son named Tosoho Tubes. Bernadus Arhita has a son named Penias Arhita. Penias Arhita has a son named Abner Arhita. Abner Arhita has a son named Amsal Arhita.

Their migration to Kaprus is also supported by the fact that they still have blood relation with Sayori clan and they are allowed by Mokiri clan to occupy Telaga Sougb. The Arhita clan can live in Kaprus as they have already obtained permission from the Mokiri clan.

\subsubsection{Iba Clan-The Sougb Tribe}

The ancestor of Iba clan is Ataha Iba. Ataha got a son named Ubarek Iba. Ubarek Iba got a son named Suboko Iba. Suboko Iba got a son named Sakohi Iba. Sakohi Iba got a son named Meref Iba. Meref Iba got a son named Iran Kokor Iba. Due to conflict and bloodshed revenge, the Iba clan moved to Kaprus in 1982. They then are allowed to settle in an area called Muspairo. Iran Kokor Iba got 4 sons named Septianus Iba, Gideon Iba, Demianus Iba, Jeri Iba, and two daughters named Apleana Iba dan Yulia Iba. It is also pointed out that the Iba clan changes their identity to Mokiri clan to get away from the bloodshed revenge. They might be found in the villages called Watintindao, Rumberpon and Isiyen. As a result, there are two classifications of Mokiri clans: Mokiri Clan that is descended from Mambo and Mokiri which is previously Iba. The Iba clan can live in Sougb Wepu Distric after they accept permission from the Mokiri clan.

\subsection{Social Movement}

Social movement can be defined as the systematic way of action in implementing and nurturing the strategy and series of coordinated movements to achieve and to secure 
the interest of a particular group. Christiansen (2009: p. 2) pointed out that there are four stages of social movement namely: emergence (very preliminary social movement with little or no organization), coalescence (organized collective movement with strategy), bureaucratization (higher level of organization that based on coalition strategy), and decline (incapability to deal with obstruction associated with success and constraints of organization). In addition, the social movement might be associated to the fear and threat from external group. Bloch (2009: p. 15) mentioned that the importance of the in-group is intensified because there is a threat imposed from another out-group. Moreover, the social movement stages are reflected clearly on the social movement initiated by the Sougb and Wepu community in Kaprus. In order to analyze the social movement, the dimension of ethnic is needed to be scrutinized. Oliver (2013: p. 19) mentioned that "the three groups of ethnic dimensions are the vertical dimension of structures of domination, the horizontal dimension of network ties and network cleavages and the temporal dimension of intergenerational transmission and these three dimensions are the analytic tools for characterizing the social location of any group so that any theory of social movements needs to pay attention to these dimensions as part of its analysis".

\subsection{Language Use}

The language use is interesting phenomenon to be analyzed as it might be related to many aspects including social, economic, and political elements. The utilization of particular language in formal domain and informal domain is likely to give both positive and negative impacts on the speakers. In his concept about language and disadvantage, Wardhaugh (1995: p. 326) mentions that people can be advantaged or disadvantaged socially or esthetically, cognitively and accidentally by the language or the variety of language you happen to speak. The reasons and motivation to use a particular language is important to be explained in order to have better understanding about language use.

The utilization of a particular language can be explained through the motive, attitude and the power embedded in particular language. Sumarsono (2008: p. 43) states that language use is related with the social class, and the movement from class to class in social class is possible because social class is not fixed social strata likes caste. Accordingly there is a strong motive that supports the utilization of a particular language by the community. The position-oriented families language use is related with close physical contact among members, a set of shared assumptions, and a preference for implicit rather than explicit meaning in communication, while the person oriented families language use relies less on these factors and communication is more explicit and more context free (Wardhaugh, 1995: p. 330). In this case, Berstein (1972 cited in Wardhaugh, 1995: p. 330) points out that position orientation emphasizes on a strong sense of social identity with some loss of personal autonomy, in contrast, the person orientation nurtures personal autonomy with low social identity. In terms of the attitude towards particular language, the identity might be the key role in determining the attitude towards language. Meyerhoff (2011: pp. 73-74) points out that attitude to language can 
be analyzed through social identity theory (language as one of potent symbol to strategically use to test and to maintain boundaries between groups) and communication accommodation theory (adapting a particular linguistic behavior in accordance to interlocutors' behavior and their attitude to interlocutors. In the light of social identity theory, the more salient of group identity, the stronger is the accentuation of the group uniformity and when the contrast is created between groups; accentuation is executed to make the differences between groups (Meyerhoff, 2011: p. 73).

\subsection{Migration}

Migration can be interpreted as the mobilization of a group of people driven by same interest/calling from one place to other place. The cohesiveness of the group as well as the main "calling" or interest and the external condition that bind the group are likely to determine the duration of the settlements. It can be permanent migration or temporary migration. In addition the external and internal conditions are likely to be reasons of migration. Internal condition might be related to curiosity and dream to explore the world while the external condition might be related to technology available and the threats from powerful enemy. To better understand migration the concept regarding the land particularly land tenure system should be scrutinized.

In relation to migration, land tenure system can be utilized as the fundamental base to analyze the reason of migration. From many concepts regarding land tenure, the author focuses only on the land tenure concept proposed by Fauzi (2002). Fauzi (2002) points out that there are three major components of land tenure system namely subject right, object right and kinds of right. In this case, subject right is related to the ownership of the land, object right is related to resources above and inside the land and kinds of right is condition, obligation, and expiration as well as limitation in controlling the land. Accordingly, in relation to migration, subject right is related to the capability to protect and to maintain the right as the owner of the land. Object right is related to resource above and below the land that is either wanted or not wanted and it influences the willingness and the capability of mobilization. The kind of right is right embedded on a group of people or state to arrange and to regulate the mobilization on particular area. Therefore, the reasons of migration are losing ownership and control over land (subject right), pursuing scarce resource and escaping from harmful resource (object right) and bundle of rights embedded in state, community, family and individuals.

\subsection{Special Autonomy}

Special autonomy law legalized in 2001 has ultimate goal to improve the welfare of the West Papuans and to put West Papuan in better position through the implementation of decentralization. However, it is crippled in two areas namely legal basis, social basis and unity basis. The legal basis is related to the fact that Provincial regulation (Peraturan Daerah Provinsi) and special region regulation (Peraturan Daerah Khusus) are not legalized yet. As a result, the government cannot function maximally. In addition, for the social basis, the special autonomy has bad image for some West Papuans. It is con- 
sidered as "blood money"; the money given to West Papua because West Papua asks for independence or the money given to West Papua for the human casualties during military operation. The unity basis is related to the fact that special autonomy indirectly create gap between West Papuans and non West Papuans, and between West Papuans (natives of particular area/"Orang Asli") and West Papuans (non natives of particular area).

As special autonomy goes hand in hand with policy regarding further establishment of new province and districts (Pemekaran), it leads to "worship of ethnicity". It creates segregation and separation as the natives of particular area (Orang Asli) asks for prioritization. As an illustration, the natives of Manokwari, the Arfak tribe, can ask for prioritization in the recruitment of civil servants. They also differentiate themselves from other West Papuans with the term "Orang Asli" (the natives of the land). In addition, the "adat" institution becomes powerful actor since they have bargaining capability with the government and the "adat" rules are also applied in some cases including access and control over land. Therefore, the special autonomy law that enables prioritization program from government through affirmation program, and the spirit to establish new province, regency and districts have nurtured worship of identity and interest to be on better position.

\section{Method and Approach}

As the main goal of the research lies on the analysis of migration, language use and the social movement, the method used is snowball sampling, interview, ethnography and participatory observation. Sumarsono (2008: p. 13) points out that the approach to scrutinize the language used by particular community to communicate with other communities can be done by combining sociolinguistics and anthropology so that the approaches used are interview and participant observation (the researcher blends with the community to do analysis and observation on their daily life). Snowball sampling is utilized to effectively obtain the valid and to make sure that the respondents interviewed are qualified. In this case, the head or the senior of each clan from Sougb, Wepu and Wondama is interviewed to obtain the data related the social movement and the language they use in formal and informal domain. The mode of interview is structured interview in which the list of open questions is systematically ordered to be answered by the respondents. In addition, the observation is implemented to closely scrutinize the daily life of Sougb and Wondama people.

\section{Result and Discussion}

The section is devoted to discuss the migration of the tribes, social movement of major clans together with the minor clans. The strategy of the major clan to strengthen their position as well as the distribution of clans in the village is also discussed.

\subsection{Migration}

From the history of the clan, it is clear about the original place of Wepu Clan, Bokoma 
Clan, Tubes Clan, Arhita Clan, and Iba Clan, and there reasons that drive the clans to migrate to Kaprus. The Wepu clan is originally from Botak Mountain in Manokwari, Bokoma clan, Tubes clan, Sayori, Arhita clan and Iba clan are originally from "dataran Isim" in Pegunungan Arfak regency. They then migrate to Kaprus. Wepu clan migrates from Bambu Island to Kaprus because they are interested to interact with the foreigner (the Dutch Evangelical post) in Kaprus. In this case, they are outreached to be Christians. Sayori clan migrates to Kaprus because they want to have better source of protein (fish) as at the high land of Isim the source of protein is only rat. They also migrate to Kaprus as they become the target of assassins (Suanggi). For this reason, they then change their family name to Sayori. I addition, the migration to Kaprus is easy as the wife of Nuko, the tribal head of Wamesa, is also from Sougb. The reason of Iba, Tubes, Arhita, Ista,and Bokoma clans to migrate to Kaprus is because of conflict. The fierce conflict ends with the condition in which these clans lose control and ownership over their land. Especially for Arhita, they become target of assassin (Suanggi) so that they change their family name into Mokiri. Moreover, there are some Kaikatui clans migrate from Kaprus to Yombekiri and Yomakan because of conflict with Bokoma and Sayori clans. Moreover, the impacts of migration and special autonomy are the strengthening of identity as natives, conflict and fragmentation regarding the power, authority and control, as well as multilingual generation.

\subsection{The Social Movement of Major Clans; A Quest to Be the Indigenous People of Teluk Wondama}

Obviously, there are four major clans who live in Kaprus village. They are Kaikatui clan, Mokiri clan, Bikiai clan, and Sayori Clan. From those major clans, the strongest one is Mokiri clan. Mokiri is not only the strongest but also the best in social movement. The social movement of the Mokiri clan can be explained based on the idea of Christiansen (2009) about the stages in social movement namely emergence (very preliminary social movement with little or no organization), coalescence (organized collective movement with strategy), bureaucratization (higher level of organization that based on coalition strategy), and decline (incapability to deal with obstruction associated with success and constraints of organization).

In terms of emergence, the movement of Mokiri clan can be scrutinized through the vertical dimension and the horizontal dimension of ethnic. In terms of the vertical dimension (the structure of domination), the class of the Kaikatui clan in the previous era is higher and stronger than then Mokiri Clan. Accordingly, the Mokiri clan tries to position themselves as partner of Kaikatui clan. This is indirectly executed by the marriage between Nukom and Tatmerje Mokiri. This is then supported by building non threatening relationship with the Kaikatui clan. This is reflected when the Mokiri clan moved to stay together with the Kaikatui clan in Yomakan because of the World War II. Moreover, the spread of Christianity enables the movement of the Mokiri clan to live in Kaprus with the Kaikatui clan.

In addition, the coalescence can be analyzed from the vertical, the horizontal and the intergenerational transmission dimension. In terms of the vertical dimension, it is ex- 
ecuted as the Kaikatui clan is weak due to conflict and massive migration to other places. This is depicted as the Mokiri clan succeeds to be the head of the village. This is then permanently strengthened and established by formulation of rule that the head of the village should be from the descendants of Mokiri clan. Moreover, the horizontal dimension is obvious in the development of allies. As explained on the history of the clan, there are several clans such as Bokoma, Tubes, and Iba that are allowed to live in District Sougb Wepu (Sougb Jaya) by the Mokiri clan. This is then strengthened by being able to communicate in Wamesa language and inter clan marriage with their allies: tubes, sayori, and bokoma. As an example, it is recorded that the wife of the head of BAPERKAM is from Mokiri clan. In terms of the intergenerational transmission dimension, the Mokiri clan tries to establish themselves as the suoerior clan. The strategy used to strengthen their position is by reformulating their history of their clan (First Version). In this case, the Mokiri clan claims themselves as the first clan that establishes their settlements and develops Kaprus. They also claim that they get the right as the eldest clan of Kaprus. This is supported by the head of four clan that live in Kaprus village namely the Bokoma clan, the Tubes clan, the Sayori Clan, the Werianggi clan as well as the head of two clans that live outside Kaprus village: the Arhita clan and the Iba clan. In this case, the head of Kaikatui and Bikiai clan believe that the Mokiri clan is not suitable as the head of the Kaprus village. The Kaikatui clan does not support the Mokiri clan as the head of the village as they are the first tribe that establishes and develops Kaprus. In adition, the Bikiai clan believes that the Bokoma clan is more capable as the leader of the village.

Furthermore, the bureaucratization can also be scrutinized from the vertical, the horizontal and the intergenerational transmission dimension. In terms of the structural dimension and the horizontal dimension, the Mokiri clan is able to recruit their allies into the structure of village institution at the capital of Sougb Wepu (Sougb Jaya) District. Mokiri is actually the Sougb people who is able to reconstruct their identity as the native of Kaprus by changing their clan as Wepu. They are closely related with their allies namely Bokoma, Tubes and Sayori. The structure of the village institution is explained in Table 1.

Table 1. The structure of the Kaprus Village Institution.

\begin{tabular}{ccc}
\hline Position & \multicolumn{2}{c}{ Sub Clan and Clan } \\
\cline { 2 - 3 } Head of District & Sub Clan & Clan/Tribe \\
Head of the Village & Mokiri & Wepu/Sougb \\
Secretary of the Village & Mokiri & Wepu/Sougb \\
\hline The head of village parliament board (BAPERKAM) & Mokiri & Wepu/Sougb \\
The Head of TPKK (The head of Village board that executes & Bokoma & Sougb \\
PNPM Mandiri program) & Tubes & Sougb \\
Ketua RT 1 (Head of vicinity) & & Wepu/Sougb \\
Ketua RT 2 (Head of vicinity) & Sayori & Wepu/Sougb \\
\hline
\end{tabular}


In addition, the intergenerational transmission dimension deals with the capability of the Mokiri clan to doctrine and to earn acceptance about their version of clan history especially from their young generation and from their allies (Bokoma clan, Tubes clan, and Iba clan). The bureaucratization stage is the strengthened formally by the change of name of the district from Kaprus to Sougb Wepu. This clearly legalizes that the indigenous people are the clans from Wepu tribe (Mokiri, Sayori and Bikiai) as well as the clans from Sougb tribe. Accordingly, the position of Kaikatui clan is minimized since the district name is changed but the village name remains Kaprus.

Moreover, the utilization of Sougb as the new name of the District Sougb is due to the fact that the district is majorly inhabited by the Sougb tribe. The Table 2 explains the distribution of clan in the five villages under Sougb Wepu (Sougb Jaya) District.

In addition, the reconstruction of Sougb clan as the native of Kaprus is also done by reformulating the history of the clan. Obviously there are three versions of clan story, but the one that majority and the leaders of Sougb clan hold on to is the first version as it strengthens their status as the clan who firstly occupy Kaprus.

\subsection{Language Use of the Clan Leaders in Informal and Formal Domain}

The language use of the clan leaders in Kaprus village is likely to be closely related to the interest to be in better position in economic, social, and political spheres. This interest is in fact triggered by the special autonomy law and further establishment of district and regency (pemekaran) that prioritizes freedom and opportunity in social, economic, politic and development program to the natives based on their locality. The context of language used in Kaprus village, motives behind the use of Wamesa language, the power of Wamesa languge and Sougb Language, and the utilization of Wamesa language in formal and informal domain are then explained to obtain better understanding about the worship of identity in Kaprus.

Wamesa is one of Austronesian language spoken in Wondama Bay area (Gleevink bay), the South West coast of Papua Barat Province in which it is positioned in the south and east of the Bird's head region to the end of Bintuni Bay (Karubuy, 2011: p. 4). The speaker of this language is now residing some areas including Teluk Wondama, Teluk Bintuni, Fakfak and Kaimana Regency (Kandami, 2010: p. 1). Wamesa language has SVO word order and it has three dialects namely Windesi, Wandamen and Bintuni

Table 2. Distribution of clans in Sougb Wepu (Sougb Jaya) District.

\begin{tabular}{cccc}
\hline Village Name & Clans & Majority Tribe & $\begin{array}{c}\text { Clan of the Head } \\
\text { of the Village }\end{array}$ \\
\hline Kaprus & $\begin{array}{c}\text { Werianggi, Mokiri, Kaikatui, Bikiai, } \\
\text { Bokoma, Tubes, Arhita and Sayori }\end{array}$ & Wepu and Sougb & Mokiri \\
Nuspairo & Iba & Sougb & Iba \\
Reyob & Mokiri, and Arhita & Sougb & Arhita \\
Yarmatum & Inden and Sayori & Sougb & Inden \\
Siresi & Sayori and Arhita & Sougb & Sayori \\
\hline
\end{tabular}


(Refwalu, 2014: pp. 2-3). In this case, the dialect spoken in Sougb Wepu (Sougb Jaya) District including Kaprus village is Windesi.

Kaprus village is the melting pot of two big ethnic namely The Sougb tribe and the Wamesa Tribe. The implementation of "pemekaran" and special autonomy law significantly change the social class of the Sougb tribe; they are the natives of Papuan but based on the locality, they are not the natives of Kaprus village. Accordingly, their position might not be accommodated by the "pemekaran" law. As a result, they try to establish their new identity as the native of Kaprus village. This is executed brilliantly by the re-creation and re-formulation of their clan history. Other strategies implemented include the naming of Districtinto Sougb Jaya (Sougb Wepu) to strengthen their position. This is not difficult, since the population of Sougb in Kaprus outnumbers the population of Kaikatua clan (Wamesa tribe) that is only 2 family units. Also, they dominate the position on village elite and use Wamesa language as the way to communicate with Wamesa people. This is in fact not difficult, as the migration of the Sougb tribe to Kaprus has been done in the past and they have lived with the Kaikatui clan that is able to speak Wamesa language, so that the descendants of Sougb tribe are bilingual because they are able to speak Wamesa, Sougb and Malay Papuan. In the past, they are the new comer to Kaprus (minority), the use of Wamesa language is a must to avoid the revenge and vendetta from their enemies. Sumarsono (2008: p. 79) mentions that the success of the minority to learn the language of the majority depends on instrumental motivation (language is perceived as instrument to achieve a goal), and integrated motivation (language is perceived as the important element that determines life in the future).

There is a positive sign about the use of Wamesa language by the leaders of the clan from the Sougb Tribe. Based on the observation, the leaders of Mokiri clan, Bikiai clan, Sayori clan, Bokoma clan, and Tubes clan use Wamesa language instead of Sougb Language in formal domain (village meeting and announcement). At the informal domain, the Wamesa language is used when they communicate with other people from Wamesa tribe (Werrianggi and Kaikatui clan). In addition, they use Sougb language, when they communicate with their family in the house, and in the garden and to exclude the speakers of Wamesa language usually between leaders of clans from Sougb tribe by using limited cover area radio. Above all the utilization of Wamesa language is possible as they social network is closed. Coates (1986: p. 79) points out that the concept of social network s one of the productive concept in linguistic and it consists of closed network (strong language norm enforcement mechanism and high density group as they know each other) and open network (weak language norm enforcement mechanism and low density as the contacts are not related). As a result, the language norm enforcement mechanism might be easily executed by the leader of Mokiri clan as the superior leaders of Bikiai, Sayori, Tubes, and Bokoma clan.

There are several reasons that motivate the leaders from Sougb tribe/clan (the leader of Mokiri Clan, the leader of Bikiai clan, the leader of Bokoma and the leader of Tubes clan) to use Wamesa language. First, using Wamesa language might strengthen their position as the natives of Kaprus village due to special autonomy and "pemekaran" im- 
plementation. Sumarsono (2008: p. 43) states that language use is related with the social class, and the movement from class to class in social class is possible because social class is not fixed social strata likes caste. Secondly, the Wamesa language is more powerful than the Sougb language. The influence direction of the interaction of two languages depends on prestige and the benefits of use a language in social, economic, culture, politics, and religion, loyalty of the speakers, power of the speaker in social, economy, culture, politics and government, and national mobilization as well as national communication system and mass media, so that if the speakers of A language has better status of those 4 elements than the speakers of B language who live close to them, the influence direction moves from A to B (Jendra, 2007: p. 82). In this case the change of direction of interaction of Wamesa language and Sougb language moves from Wamesa language to Sougb language because using Wamesa language improves the Sougb leaders position in politic, economy, culture, and identity as natives. Accordingly, they are forced to be loyal user of Wamesa language that supports their movement and mobilization to blend with other Wamesa tribes in Teluk Wondama Regency. Moreover, Mackey (1973 cited in Wijana and Rohmadi, 2010: p. 37) analyses that the power of language can be measured through several indicators: economy (Gross National Product of a country), ideology (function of language in nurturing ideology such as religion, politics and other particular belief) and culture (function of language in sustaining the richness of particular culture of community).

\section{Conclusion}

In short, the social movement of Sough and Wepu (Sough tribe that reformulates their history of clan) in Kaprus village has proved that the concept about ethnicity, race and the indigenous people always change. This might be related to the effort and the strategy used to establish a strong identity that is supported by local institution and to influence the society. Oliver (2013: p. 19) stated that "different movement carriers are in different ethnic-structural locations that affect everything about them: mobilization processes, choices of strategy and tactics, core framing tasks and consciousness raising, the likelihood of repression, and the ability to influence the larger society".

Furthermore, the use of Wamesa language by the leader of Soug especially Mokiri, Bikiai, Sayori, Bokoma and Tubes clan are fundamentally motivated by the benefits that they obtain in economic, social, ciltural, politic sphere. This is indirectly triggered by the implementation of special autonomy law and further establishment and division of new regency or district (Pemekaran). This means that, the language use is practical and directed to maximize benefit in the case of Kaprus and is embedded on the function of language. Hallyday (1977 cited in Jendra, 2007: p. 95) states that there are 6 personal functions of language: instrumental function (using a language to obtain benefit), interaction function (using a language to build relationship), personality function (using a language to shoe identity, feeling, opinion, education, experience), problem solving function (using a language to solve problem in life), imaginative function (using a language to imagine, pretend, talk fiction), and informative function (using a language to 
deliver and accept information).

The recommendation for the future research is related to the mapping of communal property (hak ulayat) and the analysis of every tribe that lives in Sougb Wepu (Sougb Jaya) District. This is important as the data might be crucial input for the local government to reduce and to minimize conflict related to claim over communal property and different perceptions about the border, the width, and control over the communal property. The insufficient knowledge and data about the local institution and tribes might lead to ineffectiveness of development effort executed by the local government.

\section{Recommendation and Lesson Learnt}

This section highlights lesson learnt and recommendation. There are three main lessons learnt. First, the migration of Sayori, Wepu, Tubes, Bokoma, Arhita, Iba, and Kaikatui is done more than decades. They are then inter-married and able to speak both Wamesa language and Sougb language. Second, the spirit to be in better position amplified with special autonomy law and willingness to establish new governance at provincial and district level have nurtured worship of ethnicity. Third, the cycle of conflict is 1) conflict about identity, 2) conflict about superiority, 3) conflict about leadership right, 4) conflict about control over natural resources, 5) conflict about priority in accepting affirmation program 6) conflict about values.

The recommendations are: 1) Strengthening nationalism. It can be done through military service, 2) Deleting the term "Orang Asli" (natives of particular area), 3) Distributing cash directly to West Papuans (40\% of Special Autonomy fund) to support education, 4) Drafting and legalizing PERDASI (Provincial Legislation) and PERDASUS (Special Regulation) that promote cohesiveness among West Papuans and 5) Implementing sustainable development concept that is in line with West Papua condition.

\section{Acknowledgements}

The research is funded by Department of Planning and Development. Teluk Wondama Regency, West Papua, Indonesia.

\section{References}

Bloch, K. (2009). Social Movement Framing and the Reproduction of Inequality: Immigrant Restrictionists Constructing Virtual Selves on the Internet. North Carolina State University.

Christiansen, J. (2009). Social Movement and Collective Behavior: Four Stages of Social Movement. EBSCO Research Starter, 1-7.

Coates, J. (1986) Women, Men and Languages: Studies in Language and Linguistics. Essex, England: Longman.

Fairclough, N. (1989). Language and Power. Essex, England: Longman.

Fauzi, N. (2002). Konflik Tenurial: Yang Diciptakan, Tapi Tak Hendak Diselesaikan. In: Anu Lounela dan R. Yando Zakaria (Eds.), Berebut Tanah: Beberapa Kajian Berperspektif Kampus dan Kampung. Yogyakarta: Insist Press.

Jendra, I. W. (2007). Sosiolinguistik Teori dan Penerapannya. Surabaya: Paramita.

Kandami, Y. (2010). Subjective and Objective Personal Pronoun of Wamesa Language. Sarjana 
Sastra Skripsi: State University of Papua.

Karubuy, T. (2011). Verbal Morphology in Wamesa Language. Sarjana Sastra Skripsi: State University of Papua.

Meyerhoff, M. (2011). Introducing Sociolinguistics. New York: Routledge.

Oliver, P. (2013). The Ethnic Dimensions: Bringing Ethnic Divisions and Conflict to the Center of Social Movements Theory.

http://www.ssc.wisc.edu/ oliver/PROTESTS/ArticleCopies/Oliver The\%20Ethnic\%20Dimensi ons Feb 2013.pdf

Refwalu, F. N. (2014). Comparative Constructions in Windesi: A Dialect of Wamesa. Sarjana Sastra Skripsi: State University of Papua.

Sumarsono (2008). Sosiolinguistik. Yogyakarta: Pustaka Pelajar.

Wardhaugh, R. (1995). An Introduction to SocioLinguistics. Oxford, United Kingdom: Blackwell Publisher.

Wijana, I. D. P., \& Rohmadi, M. (2010). Sosiolinguistik: Kajian Teori dan Analisis. Yogyakarta: Pustaka Pelajar.

Submit or recommend next manuscript to SCIRP and we will provide best service for you:

Accepting pre-submission inquiries through Email, Facebook, LinkedIn, Twitter, etc.

A wide selection of journals (inclusive of 9 subjects, more than 200 journals)

Providing 24-hour high-quality service

User-friendly online submission system

Fair and swift peer-review system

Efficient typesetting and proofreading procedure

Display of the result of downloads and visits, as well as the number of cited articles

Maximum dissemination of your research work

Submit your manuscript at: http://papersubmission.scirp.org/

Or contact aa@scirp.org 